\title{
Enzymatic activity of ACE2 regulates type 2 airway inflammation in mice
}

Asami Fukuda ${ }^{1}$, Shota Toyoshima ${ }^{1}$, Shiho Yamada ${ }^{1}$, Yusuke Kurosawa ${ }^{1}$, Yoshimichi

Okayama $^{1}$, Shuichiro Maruoka ${ }^{1}$, and Yasuhiro Gon ${ }^{1}$

${ }^{1}$ Nihon University School of Medicine

August 19, 2020

\section{Hosted file}

Fukuda_et_al_for_Allergy_letter_for_initial_submission.pdf available at https://authorea. com/users/352059/articles/476446-enzymatic-activity-of-ace2-regulates-type-2-airwayinflammation-in-mice 